Article

\title{
Household Willingness to Pay for Wastewater Treatment and Water Supply System Improvement in a Ger Area in Ulaanbaatar City, Mongolia
}

\author{
Ariuntuya Byambadorj ${ }^{1,2}$ and Han Soo Lee ${ }^{1, *(D)}$ \\ 1 Graduate School for International Development and Cooperation, Hiroshima University, 1-5-1 Kagamiyama, \\ Higashi-Hiroshima, Hiroshima 739-8529, Japan \\ 2 Urban Standard and Environmental Safety Control and Coordination Agency, \\ Ulaanbaatar City 15160-0011, Mongolia \\ * Correspondence: leehs@hiroshima-u.ac.jp; Tel.: +81-82-424-4405
}

Received: 5 July 2019; Accepted: 3 September 2019; Published: 5 September 2019

check for

\begin{abstract}
This study aimed to investigate the willingness of residents of ger (traditional nomadic house) areas to pay for improvements in the water supply and wastewater treatment system in terms of capital costs and operation and management (O\&M) costs by contingent valuation (CV) method and payment card format. The problems in the ger area are a lack of a drainage system, the use of unimproved sanitation technology, and an unsafe water supply, in addition to the direct discharging of wastewater into pit latrines, soak pits, yards, and streets. The contribution of this study is the application of this method in a previously unstudied area to enhance the participation of ger communities that are absent in the development plan of Ulaanbaatar city. A field survey was conducted in one of the ger areas, the Damba planning unit, and 298 samples were collected from residents. Data were analyzed and compared using ordinary least squares (OLS) and Tobit regression models. Model results showed that the average total willingness to pay for the water supply and wastewater treatment facility installation was 1000 thousand Mongolian tugrik (MNT), and the average total willingness to pay for the operation and management costs was a maximum of $3000 \mathrm{MNT}$ per month. The important factors affecting the residents' willingness to pay (WTP) for installation were the housing type, current monthly payment for water supply, income level, and education, in order of significance. People living in their own detached house and educated greater than high school were more willing to pay for the installation of water supply and wastewater treatment facilities. Those who were paying higher for their monthly water supply were more willing to pay for the installation cost. With respect to the WTP for O\&M cost, the WTP was associated with the family size, income level, housing, time for water access, and education, in order of significance. Families a larger number of members were more willing to pay, and low-income people were less willing to pay for O\&M. Education showed a positive influence on the WTP for O\&M. Water access time also affected the WTP of those who could not access water within $30 \mathrm{~min}$, as they indicated low WTP values.
\end{abstract}

Keywords: wastewater treatment; water supply; contingent valuation method; Tobit model; Damba district

\section{Introduction}

Access to safe water, sanitation, and sound management of freshwater ecosystems are essential to human health and to environmental sustainability and economic prosperity. Currently, water, sanitation, and hygiene (WASH) are a global concern and a priority area as the goal 6 in the sustainable development goals (SDGs) of the United Nations (UN) [1-5]. 
According to the UN [5], a majority of the world's population still lacks safe sanitation, and 3 in 10 lack safe drinking water. In $2015,71 \%$ of the global population used safely managed drinking water services (an improved water source located on premises, available when needed and free from contamination) and $17 \%$ of the population used a basic drinking water service (an improved water source not more than 30 min away). Otherwise, the remaining $13 \%$ of the global population still lacked even a basic level of service for drinking water [5].

With respect to sanitation, on the basis of estimates from 84 countries in 2015 [5], 39\% of the global population used safely managed sanitation services (basic facilities safely disposing of human waste) and an additional $29 \%$ of the population utilized a basic sanitation service (an improved facility that is not shared). In 2015, 892 million people continued to practice open defecation [4].

In 2015, conflict, violence, and instability in fragile states based on the World Bank's harmonized classification of fragile situation [6] curtailed progress on water and sanitation services [5]. Moreover, untreated wastewater from households degrades overall water quality, posing a risk to both public health and the environment.

For instance, in 2002, WASH-related deaths and disabilities occurred globally among children 14 years old and younger at rates of $25 \%$ and $22 \%$, respectively [7]. Frequently, WASH-borne illness results directly from the exclusion of the urban poor in national WASH policy, planning, and intervention processes. One of the fundamental causes of this exclusion has been the long-standing inability of utility and city managers and their advisers to plan and implement water and sanitation systems, which respond to the realities faced by the urban poor [8]. Moreover, in both urban and peri-urban (or rural) settlements, including slums, the provision of sanitation, drinking water, and wastewater treatment services is absent or ignored, particularly in low-income countries $[1,9,10]$. The peri-urban areas in Mongolia are no exception to this kind of attitude being adopted by the national government $[1,4]$.

Mongolia is a landlocked country bordered with China in the south and Russia in the north. The country is one of the least densely populated countries in the world, with an estimated population of 3.16 million in 2017, occupying an area of 1.5 million $\mathrm{km}^{2}$ [11,12]. Of the fresh water in the country, $82 \%$ is groundwater [13]. The annual mean temperature of the capital city, Ulaanbaatar, is $-3.7^{\circ} \mathrm{C}$, known as the coldest capital city in the world, with a low precipitation of approximately $200 \mathrm{~mm} /$ year $[12,14]$.

A high proportion of the country population and economy is concentrated in the capital city, having over 1.4 million people in 2016 [15]. Ulaanbaatar is experiencing on-going urban growth due to a large number of nomadic immigrants from rural areas, resulting in environmental, health, and socio-economic problems. Sixty percent of the total population of Ulaanbaatar reside in peri-urban informal settlements, called ger areas (a ger is a portable round yurt/tent used in traditional nomadic settlements), without supporting infrastructure and services for water supply, drainage, sewage, and central heating.

Moreover, Mongolia experiences climatic hazards—-these being drought and severe winters (zud is the Mongolian local term for severe winter, and $d z u d$ is the local term for the combination of drought and $z u d$ ), affecting the nomadic people in rural areas. Dzud is a major natural disaster caused by harsh climate conditions in winter/spring, causing livestock loss because of hunger due to inability of grazing [16]. Then, herders who have lost their entire livestock in rural areas have to migrate to the capital city and settle down in the ger areas. This is one of the main causes of the aforementioned urban growth of Ulaanbaatar [17].

A lack of a safe water supply and unimproved sanitation have been found to be the key issues in the ger areas. Simple, unimproved, and unventilated pit latrines and soak pits are generally used for on-site sanitation and household greywater (used water from kitchens, sinks, washing, and other household sources other than sewage and toilet), resulting in unhygienic living conditions [18]. The daily average water consumption of $7.3 \mathrm{~L}$ per person in the ger areas is low compared to the world standard of $25 \mathrm{~L}$, and far lower than the $291 \mathrm{~L}$ average used by residents of the city core in Ulaanbaatar [13]. As a result, 
less greywater is produced in the ger areas (approximately $4-5 \mathrm{~L} /$ person/day) [13]. The low usage in the ger areas can be attributed to mainly deficiencies in the water supply system.

The sanitation practices in ger areas has significant and cumulative impacts on the soil and groundwater. Although pathogens from human waste eventually degrade in the ground, these processes are slowed by the cold climate, with an average annual temperature of $1.0^{\circ} \mathrm{C}$ [19], an average summer temperature of $15^{\circ} \mathrm{C}$, and an average winter temperature of $-19^{\circ} \mathrm{C}$ [20]. The large amounts of waste going into the soil can be transported by ground water and surface water during the spring thaw and summer rains and can affect the health of the residents because of the lack of hygienic sanitation, which likely contributes directly to higher disease rates. The lack of adequate wastewater disposal systems is one barrier to increasing the quantity of water supplied to residents. The lack of basic urban services and infrastructure in the ger area settlements has become a source of urban environmental issues such as air, water, and soil pollution [20].

With respect to current states of the ger areas on services and infrastructure (e.g., water supply, sanitation, solid waste management, heating, electricity, street lighting, roads and footpaths, transportation services, flood control and drainage, health services, emergency services, education, and greening), detailed information is well described in a series of reports by the UN Habitat [20-22].

However, there are very few studies reporting on the improvement of WASH-related issues. Uddin et al. reported field experiments on greywater treatment systems, and improvements in household water supply (use) and wastewater treatment in the ger area of Ulaanbaatar [13,23]. Uddin et al. also raised WASH-borne hazards and risk issue in the ger area [1,18].

Effective water and sanitation management relies on the participation of various stakeholders, including local communities [4]. However, as described, the provision of sanitation, drinking water, and wastewater treatment services and the participation of local communities in peri-urban or rural areas are absent or ignored by the national or local governments in low-income countries $[1,9,10,24]$, including the Mongolia [1,4].

Therefore, for the participation of various stakeholders in the sustainable development plan of ger areas, this study aims to estimate the willingness to pay (WTP) of residents for improving the water supply and wastewater treatment services by using the contingent valuation (CV) method. To the extent of authors' knowledge, there is no study reported on residents' WTP for a water supply and wastewater treatment services in ger areas of Ulaanbaatar. In this study, a field survey on WTP for water and wastewater services had been conducted in a ger area defined in the development plan. Much of the literature uses the CV method to examine the WTP for non-market products and services in various contexts, for example, in carbon tax on air passengers [25], health services [26], water and wastewater services [27-36], grassland restoration [37], beach management [38], storm surge protection [39], electricity service [40], marine conservation parks [41], mortality risk reduction [42], toll road services [43], and urban forestation to mitigate climate change [44]. In all cases, the CV method allows for the obtaining of the economic valuation of the proposed non-market goods or services, on the basis of an improvement in the living conditions of the beneficiaries.

This paper is structured as follows. The study area, Damba planning unit, is described in Section 2, and the field survey, data, and methodology are presented in Section 3. The results and discussions on their implications are described in Sections 4 and 5, respectively. The conclusions, including the limitations of this study, are presented in Section 6.

\section{Study Area}

Ulaanbaatar is the capital and the largest city of Mongolia and serves as the economic and cultural center of the country (Figure 1). The Ulaanbaatar ger areas are now permanently occupied. While the housing density of the ger areas is too high for a traditional lifestyle, it is too low for the efficient provision of basic urban services to low-income households. Small ger areas could rely on the adjacent developed city core for basic urban services, but now that the ger area population has increased to over 
$58 \%$ [20] of the total city, the resulting spatial expansion is forcing new settlements many kilometers away from the developed city core area.

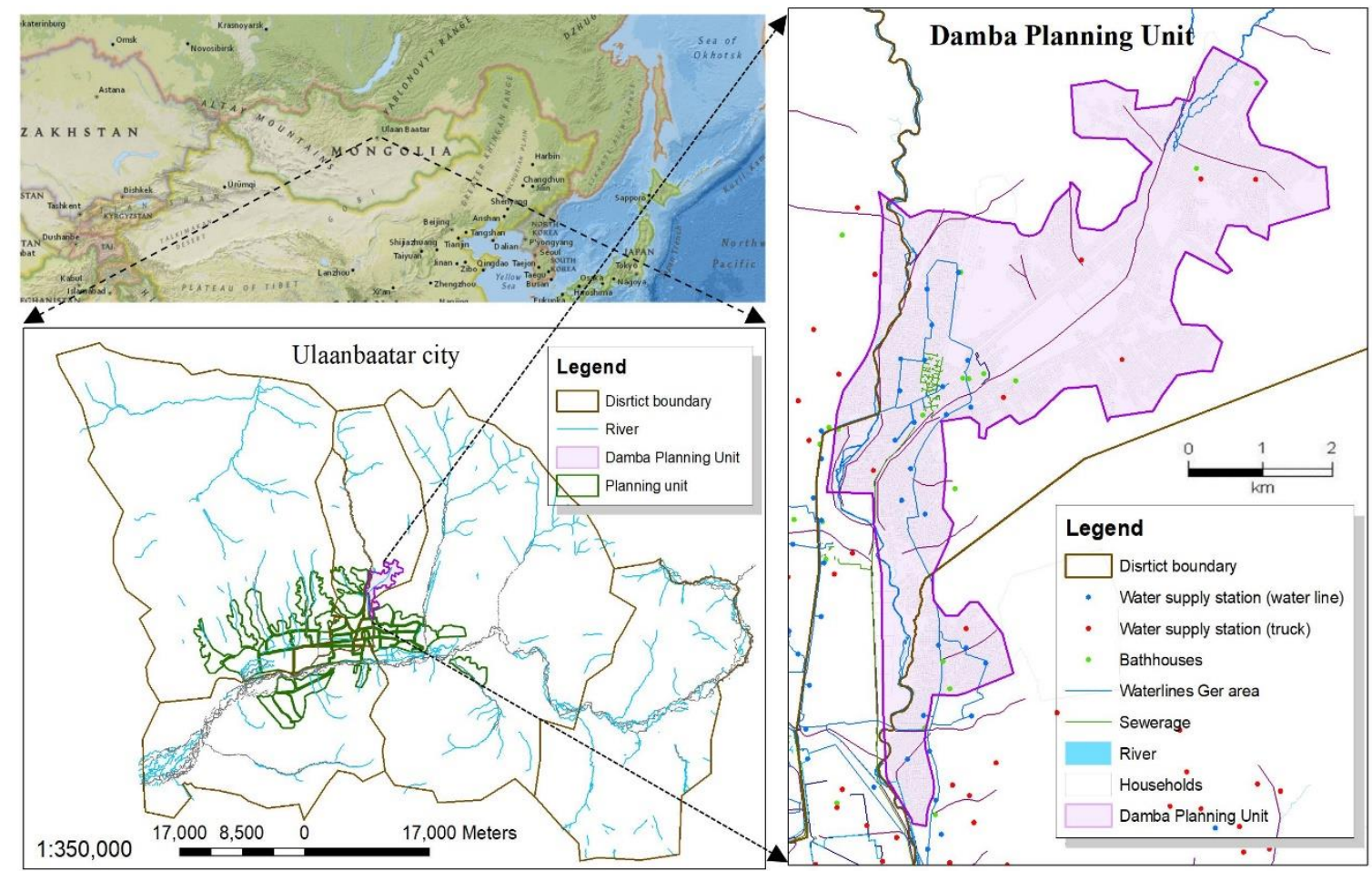

Figure 1. The study area, Damba planning unit in Ulaanbaatar City, Mongolia.

Ger areas are located around the city core (primarily to the north), and because of their lower population density, they comprise most of the settled areas of the city. Ger area buildings are rarely over two stories high. The most distinguishing feature of the ger areas is the $2 \mathrm{~m}$ high wooden fences that enclose all the residential plots and their typically irregular layout. Housing in the ger areas is predominantly single-family and is a mix of traditional gers and owner-built houses, constructed of either brick or wood.

The Damba planning unit, one of the ger districts defined by the Urban Development Trend 2030 (Figure 1), was chosen for the study area since it has one decentralized wastewater treatment plant $\left(100 \mathrm{~m}^{3}\right.$ per day) in the center, supporting a limited number of households because of the sewage line connection. Therefore, it would be useful to investigate the willingness to pay for the wastewater treatment improvement from local residents. It is located in the northeast part of Ulaanbaatar city, and residents in the area all live in ger and owner-built houses. The population of the Damba unit was approximately 32,100 , and the number of households was approximately 8700 in 2010 [45]. In the Damba area, in addition to the decentralized wastewater treatment plant, there are 20 mainline-connected water supply stations, 7 truck water supply stations, and 12 bathhouses.

\section{Data and Methodology}

\subsection{Field Survey}

The CV method consists of asking subjects about their WTP for (hypothetical) environmental, service and policy changes. The dichotomous choice format involves a binary question to a given price allowing for simplicity of use in data collection. When this elicitation method is used, the respondent is only required to answer 'yes' or 'no' when asked if a they are willing to pay a given amount for the change. The single-bounded model comprises only one such question, while in a double-bounded model the first question is followed by another, specifying a lower amount, if the answer to the first 
question was negative, and higher if otherwise [46]. The double-bounded model was shown to lead to more efficient welfare measures because it requests more information from the respondent [47]. However, the double-bounded model has been controversial because of potential inconsistency with the responses to the first binary question, since it introduces a larger scope for biased results [48]. Moreover, it was shown that there are no relevant differences in point estimates given by the two models, even for small sample size, so that neither estimator can be said to be less biased than the other [46]. Therefore, we used the single-bounded model in the following field survey.

To estimate the WTP for improving the water supply and wastewater treatment system, a field survey was conducted in the Damba planning unit in September 2017. To assess the WTP of residents for improved domestic water service, a random sampling process was used to select households in the Damba area to be interviewed. The survey team contacted 300 households by directly visiting individual households. A total of 298 questionnaires were completed with a response rate of $99 \%$. Among the 298 observations, 14 outliers were excluded from the analyses, and the remaining 284 observations were kept in the sample together with geographical information of the locations of households.

The questionnaire included five sections: (1) respondent identification, (2) household information, (3) household water supply and consumption, (4) wastewater sanitation, and (5) WTP for the cost of construction and for the operation and management (O\&M) using payment card format. The payment card format allows respondents to simply choose a WTP value and is useful as it avoids the starting point bias [39].

A household's WTP was elicited through the following two-part questioning framework:

(a) Would you be willing to pay an fee to access a water supply (WS) and wastewater treatment (WWT) facility? (Yes or No).

(b) If yes, how much would you be willing to pay for the installation (capital cost)? $(0=0,1=$ less than 1000, $2=1000-1500,3=1500-2000,4=$ higher than 2000 (thousand Mongolian tugrik (MNT); as of 4 August 2019, the currency rate is $\$ 1.00=\mp 2658.71(1 \mathrm{USD}=2658.71 \mathrm{MNT})$ ). For reference, the lowest and highest wages of Mongolians are 60.90 thousand MNT (22.91 USD) and 1120.30 thousand MNT (421.37USD) as of January 2019, according to the National Statistical Office of Mongolia).

A "No" response to item (a) implied a zero WTP in item (b).

From the 284 responses included in the analysis, 105 (37\%) indicated a zero WTP for water supply and wastewater treatment. Table 1 describes the definitions of variables used in the field survey. The original questionnaire used in the field survey can be found in the Supplementary Materials.

Table 1. Descriptions of variables used in the field survey.

\begin{tabular}{|c|c|}
\hline Variable & Description \\
\hline $\begin{array}{l}\text { Agreement of water supply (WS) and wastewater } \\
\text { treatment (WWT) facility improvement (installation) } \\
\text { payment }\end{array}$ & 1 if individual willing to pay, 0 otherwise \\
\hline $\begin{array}{l}\text { Willingness to pay WS and WWT facility installation } \\
\text { (thousand Mongolian tugrik (MNT)) }\end{array}$ & $\begin{array}{l}0=0,1=\text { less than } 1000,2=1000-1500,3=1500-2000 \\
4=\text { higher than } 2000\end{array}$ \\
\hline $\begin{array}{l}\text { Agreement of WS and WWT facility operation and } \\
\text { management (monthly) fee }\end{array}$ & 1 if individual willing to pay, 0 otherwise \\
\hline $\begin{array}{l}\text { Willingness to pay WS and WWT facility operation } \\
\text { and management fee (monthly) (thousand MNT) }\end{array}$ & $\begin{array}{l}0=0,1=\text { less than } 3,2=3-6,3=6-94=9-12 \\
5=\text { higher then } 12\end{array}$ \\
\hline Education & $\begin{array}{l}1 \text { if individual has higher than high school education, } \\
0 \text { otherwise }\end{array}$ \\
\hline Family size & Number of household member \\
\hline
\end{tabular}


Table 1. Cont.

\begin{tabular}{|c|c|}
\hline Variable & Description \\
\hline Income level 1 (thousand MNT per Month) & $\begin{array}{l}1 \text { if individual family income was less than } 300,0 \\
\text { otherwise }\end{array}$ \\
\hline Income level 2 (thousand MNT per Month) & $\begin{array}{l}1 \text { if individual family income was between } 300 \text { and } \\
700,0 \text { otherwise }\end{array}$ \\
\hline Income level 3 (thousand MNT per Month) & $\begin{array}{l}1 \text { if individual family income was between } 700 \text { and } \\
1200,0 \text { otherwise }\end{array}$ \\
\hline Income level 4 (thousand MNT per Month) & $\begin{array}{l}1 \text { if individual family income was higher than } 1200,0 \\
\text { otherwise }\end{array}$ \\
\hline Housing & $\begin{array}{l}1 \text { if individual family lives in own built house, } 0 \text { lives } \\
\text { in a ger }\end{array}$ \\
\hline Time for water access & 1 if less than $30 \mathrm{~min}, 0$ if more than $31 \mathrm{~min}$ \\
\hline Water consumption $(\mathrm{HH})$ & Water use in a week (liters) \\
\hline $\begin{array}{l}\text { Current monthly payment of water supply (thousand } \\
\text { MNT) }\end{array}$ & $\begin{array}{l}0=0,1=\text { less than } 1,2=1-3,3=3-5,4=5-7 \\
5=\text { higher than } 7\end{array}$ \\
\hline
\end{tabular}

\subsection{Contingent Valuation Method}

The WTP is used as a measure of services' price, on the basis of the assumptions of rational choice and utility maximization. If a change is proposed for a service and a person believes that the change makes them better off in some way, a person may be willing to pay for this change, and so the WTP reflects a person's economic valuation of the service in question [25].

$\mathrm{CV}$ is the most appropriate method for describing and valuing the (hypothetical) environmental changes that may be incurred through the provision of a wastewater treatment facility. The important feature that distinguishes CV from other methods (e.g., the travel cost and hedonic pricing methods) is that $\mathrm{CV}$ captures the total economic value of the benefits concerned. This means that the values derived from CV incorporate both a 'use' and a 'non-use' component. In the case of a wastewater treatment facility, the value can be defined as the household WTP for the benefits that they will receive from the use of a wastewater treatment facility. The benefits could include the reduced exposure to odors, the pollution of local ditches or streams, and the inconvenience of arranging for bathing and cleaning. The non-use value relates to an individual's WTP for the benefits in the absence of any likelihood that they will personally be a direct beneficiary [49].

WTP for non-market amenities is typically expressed using a Hicksian equivalence or a compensating surplus measure [50]. Under this approach, the parameters of the inverse Hicksian demand function are estimated. A Hicksian compensation measure of consumer i's WTP for an increase in the level of non-market amenities is given by:

$$
\mathrm{WTP}_{i}=f\left(q, Y, T_{i}\right)=\left[e_{i}\left(p^{0}, q^{0}, U^{0}\right)=Y^{0}\right]-\left[e_{i}\left(p^{0}, q^{1}, U^{0}\right)=Y^{1}\right]
$$

where $e($.$) is the consumer's expenditure function, p$ represents the price, $U$ is the respondent's utility, $Y$ is the minimum level of income necessary to maintain utility given the prices and quantities, $q^{0}$ and $q^{1}$ represent the quantities of the non-market good $q^{1}>q^{0}$, and $T_{i}$ is a vector of characteristics influencing the tastes and preferences of consumer $i$. If $Y^{1}>Y^{0}$, then $q^{1}$ is preferred to $q^{0}$, and the consumer would be willing to pay for the additional level of amenities up to the point where utility was unchanged. If $Y^{1} \leq Y^{0}$, the $q^{1}$ is not preferred to $q^{0}$, and a non-positive level of compensating surplus is implied. In this case, a corner solution is implied, and the consumer will report a zero bid in the survey on their WTP for the additional amenities offered in $q^{1}$.

Additional flexibility in the interpretation of zero bids in a WTP survey will allow the use/non-use decision implied by zero bids to be generated by a process separate from that governing the continuous 
WTP revealed by potential users. In terms of the bid function, the parameters of $f($.$) are permitted$ to vary between users and non-users. This procedure allows the variables to exert differentiated influences on the discrete use/non-use decision and the continuous WTP for the subsample of users. This distinction is important because constraining the bid function to be generated by the same processes for both users and non-users may introduce specification biases into the estimation of the bid function and may thus result in misleading inferences. Allowing such flexibility has intuitive appeal because non-users may reveal a different set of tastes and preferences for the non-market good through their zero bids [50].

The data collected for the payment and income level in the field survey were interval centered in this study. Respondents were asked how much they were willing to pay in MNT and how much their incomes were, being given several options to choose from. For example, if they chose the option 2 for the installation cost of water supply and wastewater treatment facility in the survey, one cannot know if they were willing to pay any value between 1000 and 1500 MNT, thus their WTP fell within the interval 1000-1500 MNT (see Table 1). Given the interval censored data, a Tobit regression model was employed to model determinants of WTP in this study [51,52].

\subsection{Standard Tobit Model}

In the standard Tobit model [53], there is a dependent variable $y$ that is left-censored at zero:

$$
\begin{gathered}
y_{i}^{*}=x_{i}^{\prime} \beta+\varepsilon_{i}, \\
y_{i}=\left\{\begin{array}{lll}
0 & \text { if } & y_{i}^{*} \leq 0 \\
y_{i}^{*} & \text { if } & y_{i}^{*}>0
\end{array},\right.
\end{gathered}
$$

where the subscript $i=1, \ldots, N$ indicates that the observation $y_{i}^{*}$ is an unobserved ("latent") variable, $x_{i}$ is a vector of explanatory variables, $\beta$ is a vector of unknown parameters, and $\varepsilon_{i}$ is a disturbance term.

\subsection{Censored Regression Model}

The censored regression model is a generalization of the standard Tobit model. The dependent variable can be either left-censored, right-censored, or both left-censored and right-censored, where the lower and/or upper limit of the dependent variable can be any number:

$$
\begin{gathered}
y_{i}^{*}=x_{i}^{\prime} \beta+\varepsilon_{i}, \\
y_{i}=\left\{\begin{array}{ccc}
a & \text { if } & y_{i}^{*} \leq a \\
y_{i}^{*} & \text { if } & a<y_{i}^{*}<b, \\
b & \text { if } & y_{i}^{*} \geq b
\end{array}\right.
\end{gathered}
$$

where $a$ is the lower limit, and $b$ is the upper limit of the dependent variable. If $a=-\infty$ or $b=\infty$, the dependent variable is not left-censored or not right-censored, respectively.

\subsection{Estimation Method}

Censored regression models (including the standard Tobit model) are usually estimated by the maximum likelihood (ML) method. Assuming that the disturbance term $\varepsilon$ follows a normal distribution with a mean of 0 and a variance of $\sigma^{2}$, the $\log$-likelihood function is

$$
\log L=\sum_{i=1}^{N}\left[I_{i}^{a} \log \Phi\left(\frac{a-x_{i}^{\prime} \beta}{\sigma}\right)+I_{i}^{b} \log \Phi\left(\frac{x_{i}^{\prime} \beta-b}{\sigma}\right)+\left(1-I_{i}^{a}-I_{i}^{b}\right)\left(\log \varnothing\left(\frac{y_{i-} x_{i}^{\prime} \beta}{\sigma}\right)-\log \sigma\right)\right],
$$


where $\varnothing($.$) and \Phi($.$) denote the probability density function and the cumulative distribution function,$ respectively, of the standard normal distribution, and $I_{i}^{a}$ and $I_{i}^{b}$ denote indicator functions with

$$
\begin{aligned}
& I_{i}^{a}=\left\{\begin{array}{ll}
1 & \text { if } y_{i}=a \\
0 & \text { if } y_{i}>a
\end{array},\right.
\end{aligned}
$$

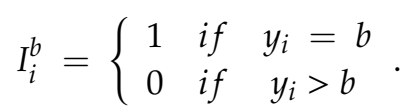

The log-likelihood function of the censored regression model, Equation (5), can be maximized with respect to the parameter vector $\left(\beta^{\prime}, \sigma^{\prime}\right)$ using standard non-linear optimization algorithms.

In this study, the analysis results of the ordinary least squares (OLS) estimation method were compared to the Tobit analysis results. It should be noted that there were limitations in the estimates of the OLS model due to potential sample selection bias and censored data.

\subsection{Marginal Effect}

The marginal effect indicates the effect of a change in the $j$ th variable on a dependent variable of $x$. The marginal effects of an explanatory variable on the expected value of the dependent variable is [53]

$$
M E_{i}=\frac{\partial E[y \mid x]}{\partial x_{i}}=\beta_{j}\left[\Phi\left(\frac{b-x^{\prime} \beta}{\sigma}\right)-\Phi\left(\frac{a-x^{\prime} \beta}{\sigma}\right)\right],
$$

where $M E_{i}$ is the marginal effect of the $j$ th explanatory variable, $a$ is the lower limit, and $b$ is the upper limit of the dependent variable. $\beta$ is a vector of unknown parameters of the $j$ th explanatory variable, and $\Phi($.$) is the cumulative distribution function.$

\section{Results}

\subsection{Descriptive Survey Results}

Figure 2 illustrates the summary of field survey on WTP for water supply and wastewater treatment in the Damba planning unit. Table 2 shows the current water supply and wastewater treatment facility types and the number of respondents. In the study area, $98.1 \%$ of the respondents can access an improved water supply but only $23.7 \%$ said they were satisfied, $66.4 \%$ said it was just passable, and $8 \%$ said they were unsatisfied with the water quality. Eight percent of the respondents could use improved wastewater treatment and sanitation facilities, while $92 \%$ of the respondents could not use improved wastewater treatment and sanitation facilities.

A number of factors were hypothesized to be relevant to the revealed WTP for improving the water supply and wastewater treatment conditions. The dummy variable in the bid function was equal to 1 if the residents' education was greater than high school and otherwise was equal to 0 . Additionally, if the residents lived in their own built house, then the dummy variable was equal to 1 ; otherwise, it became 0 . The expected effect of water access time and housing on WTP is uncertain. Residents living in their own built house were hypothesized to have more opportunities to improve their water conditions; thus, they were expected to have a greater WTP for the improved water supply and wastewater treatment. Four categorical income variables were defined to represent monthly income levels. WTP was expected to increase as income increased and water consumption increased. The expected effect of the current monthly payment and education on water supply (thousand MNT) was unclear. 


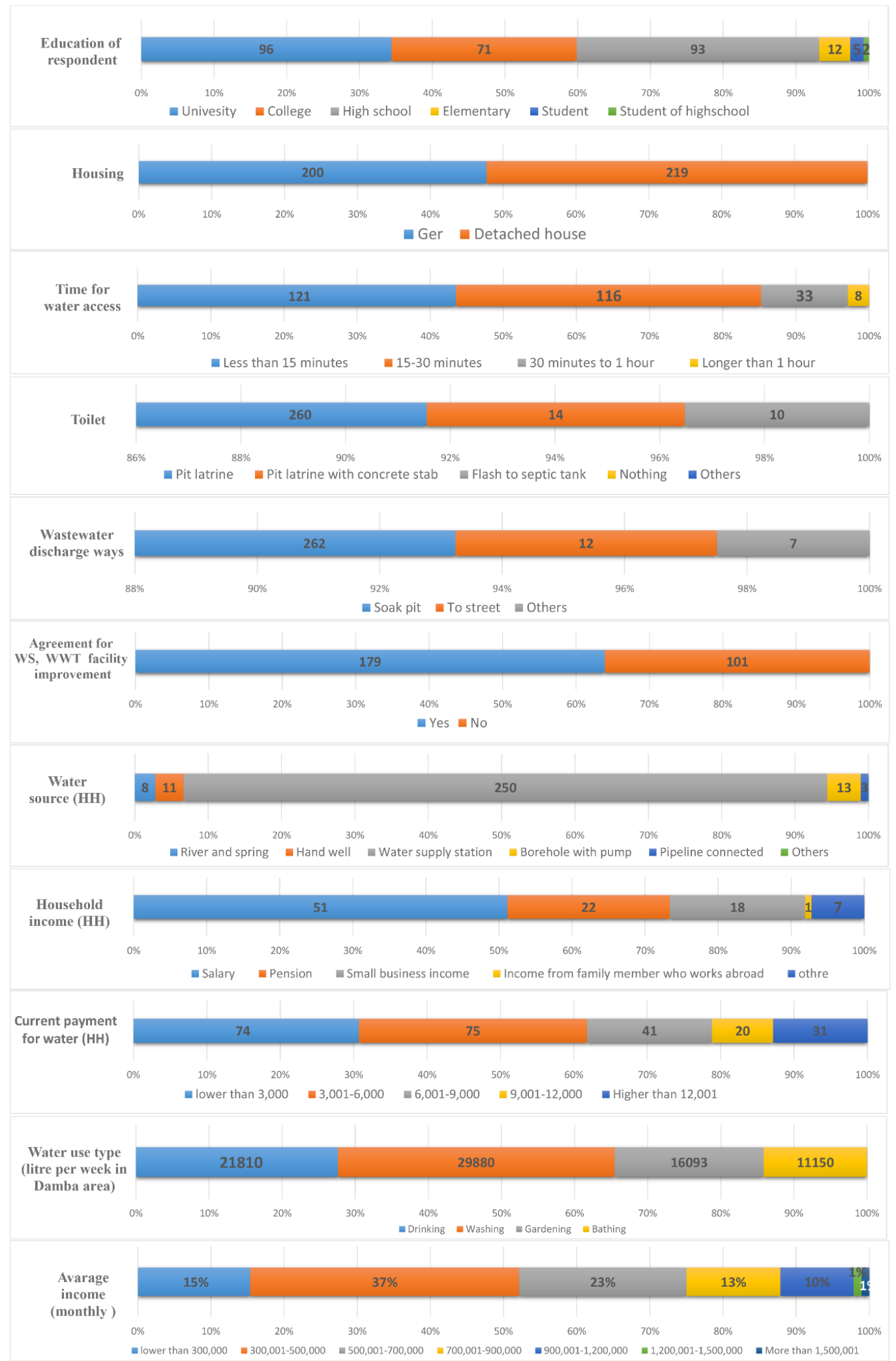

Figure 2. Summary of field survey on willingness to pay (WTP) for water supply and wastewater treatment in the Damba planning unit, Ulaanbaatar, Mongolia. 
Table 2. Survey results on water supply and wastewater treatment facility.

\begin{tabular}{ccccc}
\hline Facility & Improved & & Unimproved \\
\hline \multirow{3}{*}{ Drinking water } & Hand well & 11 & River and spring & 8 \\
& Water supply station & 250 & & \\
& Borehole with pump & 13 & & 260 \\
& Pipeline connected & 3 & Pit latrine & 0 \\
\hline \multirow{2}{*}{ Sanitation } & Pit latrine with concrete stab & 14 & Nothing & \\
& Flash to septic tank & 10 & &
\end{tabular}

A summary of the statistics for the entire sample and for the censored and uncensored sub-samples are presented in Table 3. The mean WTP for the water supply and the improved wastewater treatment facility installation for the entire sample was less than 1000 (thousand MNT). In the subsample (62.8\%) that answered "yes" on question F1 ("If there is a chance to improve the water supply and the wastewater (sanitation) conditions, how much would you pay for it?"), the WTP for the installation of the water supply and wastewater treatment facility was 1500 (thousand MNT).

The mean WTP for the O\&M of the water supply and wastewater treatment improvement facility from the entire sample was less than 3 (thousand MNT). In the subsample (66.3\%) that answered "yes" on question F7 ("If answer F-1 is yes, what would you pay for water, wastewater, and sanitation fees for monthly (O\&M)?"), the WTP for O\&M was 6 (thousand MNT).

A greater proportion of the respondents that indicated a zero bid on both the installation and the O\&M WTP were from lower income categories (income levels 1 and 2).

In the subsample indicating a positive WTP for the installation of the water supply and wastewater treatment facility, $62 \%$ of the respondents had an education level greater than high school, $9 \%$ were at income level 1, 41\% were at income level 2, 8\% were at income level 3, 3\% were at income level $4,71 \%$ lived in a detached house, $87 \%$ could access water within $30 \mathrm{~min}$, and $88 \%$ were willing to pay for O\&M. In addition, in terms of WTP for the installation, 139 respondents (73.5\%) from the subsample answered option 1 (less than 1000 thousand MNT), 40 (21.2\%) chose option 2 (between 1000 and 1500 thousand MNT), 7 (3.7\%) chose option 3 (between 1500 and 2000 thousand MNT), and 3 $(1.6 \%)$ answered option 4 (more than 2000 thousand MNT).

In the subsample indicating a positive WTP for the O\&M of the water supply and wastewater treatment improvement, $65 \%$ of the respondents had an education level greater than high school, $12 \%$ were at income level 1,37\% were at income level 2, 8\% were at income level 3,3\% were at income level $4,68 \%$ lived in a detached house, $85 \%$ could access water within $30 \mathrm{~min}$, and $84 \%$ were willing to pay for the facility installation. In addition, in terms of WTP for O\&M, 74 respondents (30.1\%) from the subsample answered option 1 (less than $1000 \mathrm{MNT}$ ), 75 (31.1\%) chose option 2 (between 3000 and 6000 MNT), 41 (17.0\%) chose option 3 (between 6000 and 9000 MNT), 20 (8.3\%) answered option 4 (between 6000 and $9000 \mathrm{MNT}$ ), and 31 (13.5\%) answered option 5 (more than 12,000 MNT).

People who had an education level greater than high school were willing to pay more. The effect of water access time was that those who could not access water within $30 \mathrm{~min}$ had a lower WTP. People who lived in their own built house were willing to pay more. 
Table 3. Statistics of variables relevant to WTP for water supply and wastewater treatment.

\begin{tabular}{|c|c|c|c|c|c|c|c|c|c|c|c|c|c|}
\hline \multirow{3}{*}{ Item } & \multirow[b]{3}{*}{ Mean } & \multirow{2}{*}{\multicolumn{3}{|c|}{ Total Sample }} & & \multicolumn{4}{|c|}{ WTP for Installation } & \multicolumn{4}{|c|}{$\begin{array}{l}\text { WTP for Operation and } \\
\text { Management (O\&M) }\end{array}$} \\
\hline & & & & & & \multicolumn{2}{|c|}{ Yes } & \multicolumn{2}{|c|}{ No } & \multicolumn{2}{|c|}{ Yes } & \multicolumn{2}{|c|}{ No } \\
\hline & & SD & $\min$ & $\max$ & $\begin{array}{l}\text { No. } \\
\text { Respondents }\end{array}$ & Mean & SD & Mean & SD & Mean & SD & Mean & SD \\
\hline $\begin{array}{l}\text { Agreement of WS and WWT facility improvement } \\
\text { (installation) payment }\end{array}$ & 0.639 & 0.481 & 0 & 1 & 280 & - & - & - & - & 0.840 & 0.367 & 0.208 & 0.408 \\
\hline $\begin{array}{l}\text { Willingness to pay WS and WWT facility installation } \\
\text { (thousand MNT) }\end{array}$ & 0.827 & 0.785 & 0 & 4 & 249 & 1.206 & 0.663 & - & - & 1.044 & 0.766 & 0.258 & 0.510 \\
\hline $\begin{array}{l}\text { Agreement of WS and WWT facility operation and } \\
\text { management (monthly) fee }\end{array}$ & 0.708 & 0.456 & 0 & 1 & 255 & 0.908 & 0.290 & 0.330 & 0.473 & - & - & - & - \\
\hline $\begin{array}{l}\text { Willingness to pay WS and WWT facility operation and } \\
\text { management fee (monthly) (thousand MNT) }\end{array}$ & 1.708 & 1.546 & 0 & 5 & 241 & 2.260 & 1.432 & 0.728 & 1.241 & 2.437 & 1.286 & - & - \\
\hline Education & 0.599 & 0.491 & 1 & 6 & 279 & 0.634 & 0.483 & 0.525 & 0.502 & 0.661 & 0.475 & 0.434 & 0.499 \\
\hline Family size & 3.489 & 1.586 & 1 & 9 & 282 & 3.598 & 1.691 & 3.343 & 1.379 & 3.587 & 1.617 & 3.224 & 1.457 \\
\hline Income level 1 (thousand MNT per month) & 0.151 & 0.359 & 0 & 1 & 43 & 0.089 & 0.286 & 0.257 & 0.439 & 0.116 & 0.322 & 0.231 & 0.424 \\
\hline Income level 2 (thousand MNT per month) & 0.372 & 0.484 & 0 & 1 & 167 & 0.408 & 0.493 & 0.307 & 0.464 & 0.365 & 0.483 & 0.372 & 0.486 \\
\hline Income level 3 (thousand MNT per month) & 0.067 & 0.250 & 0 & 1 & 64 & 0.084 & 0.278 & 0.040 & 0.196 & 0.079 & 0.271 & 0.038 & 0.194 \\
\hline Income level 4 (thousand MNT per month) & 0.021 & 0.144 & 0 & 1 & 6 & 0.034 & 0.180 & 0 & 0 & 0.026 & 0.161 & 0.013 & 0.113 \\
\hline Housing & 0.668 & 0.472 & 1 & 6 & 219 & 0.713 & 0.453 & 0.590 & 0.494 & 0.690 & 0.464 & 0.590 & 0.495 \\
\hline Time for water access & 0.853 & 0.355 & 1 & 4 & 278 & 0.886 & 0.319 & 0.810 & 0.394 & 0.866 & 0.342 & 0.813 & 0.392 \\
\hline Water consumption $(\mathrm{HH})$ & 298 & 276 & 20 & 2000 & 264 & 301 & 283 & 290 & 262 & 306 & 297 & 281 & 231 \\
\hline $\begin{array}{l}\text { Current monthly payment of water supply (thousand } \\
\text { MNT) }\end{array}$ & 1.919 & 1.215 & 0 & 5 & 269 & 2.096 & 1.173 & 1.554 & 1.189 & 1.978 & 1.156 & 1.795 & 1.354 \\
\hline
\end{tabular}

$$
\text { MNT) }
$$




\subsection{Modeling Results}

To determine which factors affected individual's WTP for water supply and wastewater treatment and by how much, the results relied on the OLS and Tobit analysis. With respect to the WTP for the installation, the OLS and Tobit analysis results are presented in Table 4. The significance of the individual variables in the WTP for the installation was very similar between the OLS and Tobit models' estimations. The results indicated that the housing, household income, education, and current monthly payment for water supply had significant impacts on WTP for installation in order of importance based on the OLS result, whereas the housing, current monthly payment, education, and household income were significant in that order of importance from the Tobit analysis. On the basis of both results, the household income (in level 1) depicted a negative influence on WTP for installation.

Table 4. Result of WTP for installation of water supply and wastewater treatment system from ordinary least squares (OLS) and the Tobit model.

\begin{tabular}{|c|c|c|c|c|c|}
\hline \multirow{3}{*}{ Item } & \multicolumn{5}{|c|}{ WTP for Installation } \\
\hline & \multirow{2}{*}{\multicolumn{2}{|c|}{$\begin{array}{c}\text { OLS } \\
\text { Coefficient }\end{array}$}} & \multicolumn{3}{|c|}{ Tobit } \\
\hline & & & \multicolumn{2}{|c|}{ Coefficient } & \multirow[t]{2}{*}{ Marginal Effect } \\
\hline Intercept & -0.132 & & -0.963 & & \\
\hline Education & 0.119 & * & 0.193 & * & 0.138 \\
\hline Family size & 0.050 & & 0.075 & & 0.053 \\
\hline Income level 1 (thousand MNT per month) & -0.362 & * & -0.610 & * & -0.435 \\
\hline Income level 2 (thousand MNT per month) & -0.077 & & -0.057 & & -0.041 \\
\hline Income level 3 (thousand MNT per month) & 0.045 & & 0.002 & & 0.001 \\
\hline Income level 4 (thousand MNT per month) & 0.379 & & 0.443 & & 0.316 \\
\hline Housing & 0.340 & $* *$ & 0.461 & $* *$ & 0.329 \\
\hline Time for water access & -0.057 & & -0.116 & & -0.082 \\
\hline Water consumption $(\mathrm{HH})$ & -0.001 & & -0.001 & & -0.0001 \\
\hline $\begin{array}{l}\text { Current monthly payment of water supply } \\
\text { (thousand MNT) }\end{array}$ & 0.101 & * & 0.194 & $* *$ & 0.139 \\
\hline $\log$ sigma & & & 0.348 & & \\
\hline log-likelihood & -250.003 & & -279.516 & & \\
\hline Multiple R-squared & 0.155 & & & & \\
\hline$p$-value & 0.0001 & & & & \\
\hline
\end{tabular}

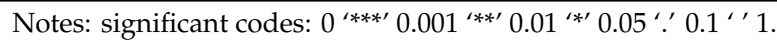

With respect to the WTP for the O\&M, the OLS, and Tobit analysis results are presented in Table 5. The significances of the individual variables in the WTP for the O\&M from the OLS result were the household income level 1, level 2, level 3, housing, and time for water access in that order, with $0.1 \%$, $5 \%, 5 \%, 10 \%$, and $10 \%$, respectively. On the other hand, from the Tobit analysis result, the family size indicated the most significant impact with $0.1 \%$, followed by the household income level 1, level 2, housing, time for water access, and education, with 5\%,5\%,10\%,10\%, and $10 \%$, respectively. In the OLS result, all significant factors except for housing had negative impacts on the WTP for O\&M, while in the Tobit result, family size and housing exhibited positive influences on the WTP for O\&M. 
Table 5. Result of WTP for operation and management of water supply and wastewater treatment systems from ordinary least squares (OLS) and the Tobit model.

\begin{tabular}{|c|c|c|c|c|c|}
\hline \multirow{3}{*}{ Item } & \multicolumn{5}{|c|}{ WTP for Operation and Management (O\&M) } \\
\hline & \multirow{2}{*}{\multicolumn{2}{|c|}{$\begin{array}{c}\text { OLS } \\
\text { Coefficient }\end{array}$}} & \multicolumn{3}{|c|}{ Tobit } \\
\hline & & & Coeffici & ent & Marginal Effect \\
\hline Intercept & 0.548 & & -0.379 & & \\
\hline Education & 0.118 & & 0.225 & & 0.177 \\
\hline Family size & 0.288 & & 0.347 & $* * *$ & 0.273 \\
\hline Income level 1 (thousand MNT per month) & -0.709 & $* * *$ & -0.934 & * & -0.735 \\
\hline Income level 2 (thousand MNT per month) & -0.520 & * & -0.599 & * & -0.471 \\
\hline Income level 3 (thousand MNT per month) & -0.039 & * & -0.037 & & -0.029 \\
\hline Income level 4 (thousand MNT per month) & -0.248 & & -0.329 & & -0.259 \\
\hline Housing & 0.382 & $\cdot$ & 0.469 & & 0.369 \\
\hline Time for water access & -0.216 & . & -0.285 & & -0.224 \\
\hline Water consumption $(\mathrm{HH})$ & -0.001 & & -0.001 & & -0.001 \\
\hline $\begin{array}{l}\text { Current monthly payment of water supply } \\
\text { (thousand MNT) }\end{array}$ & 0.099 & & 0.116 & & 0.092 \\
\hline Log-sigma & & & 0.577 & $* * *$ & \\
\hline Log-likelihood & -394.304 & & -387.396 & & \\
\hline Multiple R-squared & 0.191 & & & & \\
\hline$p$-value & 0.000 & & & & \\
\hline
\end{tabular}

Notes: significant codes: $0^{\star * * * \prime} 0.001^{\star * * \prime} 0.01^{\star * \prime} 0.05^{\prime \prime} 0.1^{\prime \prime} 1$.

The additional information on the goodness of fit statistics and the evaluation of the model fit can be found in Appendix A.

\section{Discussion}

In this study, the determinant of the WTP for installation and O\&M were analyzed using the OLS and Tobit models. In the OLS model result, there may have been some issues due to potential sample selection bias and censored data. However, by comparing the results between the OLS and Tobit models, the consistency of parameter estimates can be determined in the WTP for installation and O\&M.

First, in both results of the WTP for installation from the OLS and Tobit models, the parameter estimates were very consistent in that housing was the most significant factor, followed by household income, education, and current monthly payment for water supply. In each case of the WTP for installation, people who lived in their own detached houses were more willing to pay for the installation of water supply and wastewater treatment facilities and services. The detached houses in ger areas were more permanent settlement types than the round tents. Thus, it can be concluded that people who settled longer in a permanent housing type showed more WTP for installation. Furthermore, people who were educated (greater than high school) and who paid more currently for water showed more positive significance with a high WTP. Income level 1 was negatively significant, indicating that low-income people had a lower WTP.

Second, in both results of the WTP for O\&M, people who had a low income (income levels 1 and 2) were less willing to pay for O\&M. In the Tobit model result, family size was the most important factor for the WTP with a $0.1 \%$ level, while it was not a significant factor in the OLS result. Families with larger numbers of members were more willing to pay for O\&M. In both results, people who accessed water within $30 \mathrm{~min}$ were more willing to pay and people who were educated greater than high school showed more WTP for O\&M. It is interesting that the housing type was not that much of a significant factor in the WTP for O\&M as it was the most important factor in the WTP for installation of water supply and wastewater treatment. People who lived in a detached house were negatively significant. 
With respects to the WTP for water and wastewater services in Canberra, Australia, the WTP depended on the interruption time of water service and overflow time of wastewater. Moreover, the respondents valued those that traditionally receive less attention by water utilities, such as customer call [27]. In a survey of 21 shrinking U.S. cities, the temporal dynamic of WTP for water and wastewater service was investigated and the result indicated that the influencing geographic and socioeconomic factors (e.g., age, income) were changing as well. Therefore, it highlighted that public perceptions should be periodically investigated to continually identify times of greater public support and needs for water and wastewater service [28]. For the drinking water service in Parral, Mexico, at the time of 2009, the WTP for safe drinking water service was 1.8 to $7.55 \%$ of reported household income [30]. In the case of Puno, Peru, the WTP for improvements in the wastewater treatment system was investigated by household field survey, and the result indicated that the mean WTP of \$1.46 USD estimated was affected by socioeconomic variables such as household budget, educational level, and geographic location of the household [32]. These results, particularly those of Mexico and Peru, indicate that the affecting socioeconomic factors on WTP, such as household income, education level, and location, are similar with this Mongolian case, as the people living in their own detached house were more willing to pay.

In the individual's WTP in the CV method survey, there are several concerns related to bias, and these potential biases associated with the CV method are stated in Lantz et al. [54], including protest votes and 'yea-sayers'. Respondents may strategically state a WTP rather than stating how much they would (and could) actually pay [39]. In recent literature, it is indicated that the WTP estimated in CV method studies can be as much as two to three times actual WTP in markets, and methodology to reduce the hypothetical bias is introduced [55-58]. However, additional questions to the WTP questions to identify the protest votes or yea-sayers were not implemented in the field survey of this study. Therefore, the actual amount of payment that the respondents can pay for the water supply and wastewater treatment could be much lower than the answers to the questions.

The questionnaire used in the survey did not include any variables related to nomadic culture. Thus, it would be important to investigate how the nomadic culture influences the WTP for water supply and wastewater treatment in a future study.

\section{Conclusions}

This study aimed to estimate the WTP of ger residents for the installation and O\&M costs of improved water supply and wastewater treatment services in Ulaanbaatar city, on the basis of a field survey in Damba planning unit using the CV method.

The Tobit model result of the field survey indicated that the important factors affecting the WTP for installation were the housing type, current monthly payment for water supply, income level, and education, in order of significance. People living in their own detached house and who were educated greater than high school were shown to be more willing to pay for the installation of water supply and wastewater treatment facilities. Those who were paying higher for their monthly water supply were more willing to pay for the installation cost.

In terms of the WTP for O\&M cost, WTP was associated with the family size, income level, housing, time for water access, and education, in order of significance from the Tobit model. Families with a larger number of members were more willing to pay, and low-income people were less willing to pay for O\&M. Education showed a positive influence on the WTP for O\&M. Water access time also affected the WTP of those who could not access water within $30 \mathrm{~min}$, as they indicated low WTP values.

The average total WTP for the water supply and wastewater treatment facility installation was less than 1000 thousand MNT, and the average total WTP for the O\&M was less than 3000 MNT.

In comparison of the WTP for water and wastewater service in other countries, it was found that more information on the service and related plan given to people plays a positive role in the WTP, and that socioeconomic factors are very important in WTP. As indicated in the temporal dynamic of 
WTP in the U.S. case study [28], it is necessary to continuously investigate the WTP of ger areas and the effects of nomadic culture in water and wastewater services.

In this study, the potential bias in the survey result due to protest votes or yea-sayers was not eliminated. Thus, the actual amount of payment for water supply and wastewater treatment services could be less than the answers from the respondents. Also, the nomadic cultural influence on the WTP was not dealt with in this survey. Therefore, these limitations should be improved in future studies.

We hope that this study of the WTP for the water supply and wastewater treatment based on field survey results can encourage public participation in the urban decision-making process and assist various planners and authorities in formulating a suitable plan for the ger area development in Ulaanbaatar city, Mongolia.

Supplementary Materials: The questionnaire items used in the field survey in the Damba planning unit is provided as a supplementary material. The following are available online at http://www.mdpi.com/2073-4441/11/9/1856/s1, Table S1: Questionnaire items in Mongolian and English used in the field survey.

Author Contributions: A.B. developed the concept of this study under the supervision of H.S.L. The analysis was carried out by both authors. Both authors drafted the first version of the manuscript and worked on improving and finalizing the manuscript.

Funding: This research is partly supported by the Grant-in-Aid for Scientific Research (17K06577) from Japan Society for the Promotion of Science (JSPS), Japan.

Acknowledgments: The first author is supported by The Project for Human Resource Development Scholarship (JDS), Japan.

Conflicts of Interest: The authors declare no conflict of interest.

\section{Appendix A}

The goodness of fit statistics and the evaluation of the model fit are as follows.

In the OLS model result: multiple R-squared $=0.103$, adjusted R-squared $=0.062$, f-statistic $=2.504$ on 10 and $218 \mathrm{DF}$, and $p$-value $=0.007255$ for the WTP for installation. For the WTP for O\&M in the OLS remodel result: multiple R-squared $=0.17$, adjusted R-squared $=0.13$, f-statistic $=4.183$ on 10 and $205 \mathrm{DF}$, and $p$-value $=2.763 \times 10^{-5}$.

The summary of censoring in the Tobit model was that 2 were left-censored, 214 were uncensored, and 0 were right-censored in 216 samples in WTP for O\&M. In the case of WTP for installation, 57 were left-censored, 172 were uncensored, and 0 were right-censored in 229 samples. Table A1 depicts the fitness statistics of the model results.

Table A1. The fitness statistics, Akaike information criteria (AIC) and Bayesian information criteria (BIC), of the models.

\begin{tabular}{cc}
\hline \multicolumn{1}{c}{ Tobit Model } & OLS \\
\hline WTP Installation & WTP Installation \\
Log-Lik $=-291.495$ & \\
AIC $=606.990(\mathrm{df}=12)$ & AIC $=545.870$ \\
BIC $=648.195$ & BIC $=587.074$ \\
\hline WTP O\&M & WTP O\&M \\
Log-Lik $=-343.060$ & \\
AIC $=710.119(\mathrm{df}=12)$ & AIC $=707.603$ \\
BIC $=750.622$ & BIC $=748.106$ \\
\hline
\end{tabular}

The following Figure A1 shows histograms illustrating the censoring in the data. 

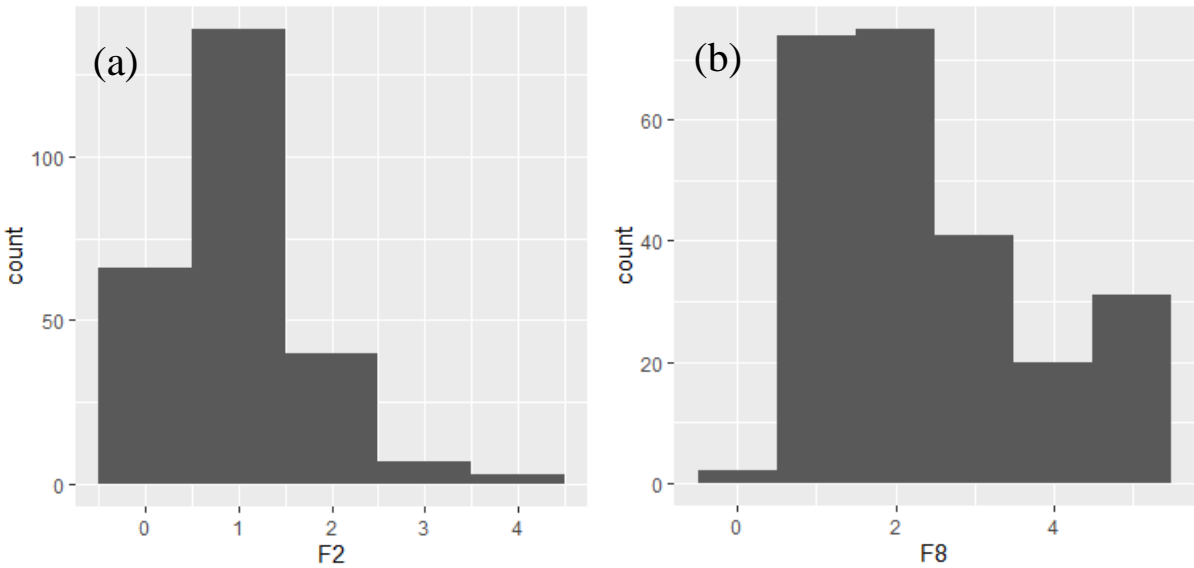

Figure A1. Histograms showing the censoring in the data; (a) WTP for installation and (b) WTP for $\mathrm{O} \% \mathrm{M}$. The count indicates the frequency. For the $x$-axis label, please refer to Table 1.

\section{References}

1. Uddin, S.M.N.; Li, Z.; Gaillard, J.; Tedoff, P.F.; Mang, H.-P.; Lapegue, J.; Huba, E.M.; Kummel, O.; Rheinstein, E. Exposure to WASH-borne hazards: A scoping study on peri-urban Ger areas in Ulaanbaatar, Mongolia. Habitat Int. 2014, 44, 403-411. [CrossRef]

2. Daudey, L. The cost of urban sanitation solutions: A literature review. J. Water Sanit. Hyg. Dev. 2017, 8, 176-195. [CrossRef]

3. Jiménez, A.; Cortobius, M.; Kjellén, M. Water, sanitation and hygiene and indigenous peoples: A review of the literature. Water Int. 2014, 39, 277-293. [CrossRef]

4. UN. Progress towards the Sustainable Development Goals; United Nations: New York, NY, USA, 2017.

5. UN. The Sustainable Development Goals Report 2018; United Nations: New York, NY, USA, 2018.

6. Bank, T.W. Harmonized List of Fragile Situations. Available online: http://www.worldbank.org/en/topic/ fragilityconflictviolence/brief/harmonized-list-of-fragile-situations (accessed on 13 April 2018).

7. WHO. Recommendations (3rd ed) in Guidelines for Drinking-Water Quality, Incorporating 1st and 2nd Addenda; World Health Organization: Geneva, Switzerland, 2008.

8. Evans, B. Understanding the Urban Poor's Vulnerabilities in Sanitation and Water Supply; Center for Sustainable Urban Development: Leeds, UK, 2007.

9. Scott, P.; Cotton, A.; Khan, M.S. Tenure security and household investment decisions for urban sanitation: The case of Dakar, Senegal. Habitat Int. 2013, 40, 58-64. [CrossRef]

10. Winters, M.S.; Karim, A.G.; Martawardaya, B. Public Service Provision under Conditions of Insufficient Citizen Demand: Insights from the Urban Sanitation Sector in Indonesia. World Dev. 2014, 60, 31-42. [CrossRef]

11. UN World Population Prospects (2017 Revision). Available online: https://population.un.org/wpp/ (accessed on 30 May 2018).

12. Hauck, M. Epiphytic lichens indicate recent increase in air pollution in the Mongolian capital Ulan Bator. Lichenologist 2008, 40, 165-168. [CrossRef]

13. Uddin, S.M.N.; Li, Z.; Adamowski, J.F.; Ulbrich, T.; Mang, H.-P.; Ryndin, R.; Norvanchig, J.; Lapegue, J.; Wriege-Bechthold, A.; Cheng, S. Feasibility of a 'greenhouse system' for household greywater treatment in nomadic-cultured communities in peri-urban Ger areas of Ulaanbaatar, Mongolia: An approach to reduce greywater-borne hazards and vulnerability. J. Clean. Prod. 2016, 114, 431-442. [CrossRef]

14. Altansukh, O. Surface Water Quality Assessment and Modelling A case study in the Tuul River, Ulaanbaatar City, Mongolia; International Institute for Geo-Information Science and Earth Observation: Enschede, the Netherlands, 2008.

15. NSOM. Mongolian Statistical Yearbook 2017; National Statistics Office of Mongolia: Ulaanbaatar, Mongolia, 2018.

16. Nandintsetseg, B.; Greene, J.S.; Goulden, C.E. Trends in extreme daily precipitation and temperature near lake Hövsgöl, Mongolia. Int. J. Clim. 2007, 27, 341-347. [CrossRef] 
17. Goulden, C.E.; Mead, J.; Horwitz, R.; Goulden, M.; Nandintsetseg, B.; McCormick, S.; Boldgiv, B.; Petraitis, P.S. Interviews of Mongolian herders and high resolution precipitation data reveal an increase in short heavy rains and thunderstorm activity in semi-arid Mongolia. Clim. Chang. 2016, 136, 281-295. [CrossRef]

18. Uddin, S.M.N.; Li, Z.; Mang, H.-P.; Schüßler, A.; Ulbrich, T.; Huba, E.M.; Rheinstein, E.; Lapegue, J. Opportunities and challenges for greywater treatment and reuse in Mongolia: Lessons learnt from piloted systems. J. Water Reuse Desalin. 2014, 4, 182-193. [CrossRef]

19. NRSO. Mongolian Statistical Year Book; National Registration and Statistics Office: Ulaanbaatar, Mongolia, 2015.

20. UN-Habitat. City Environment and Development Review; United Nations: Washington, DC, USA, 2010.

21. UN-Habitat. Service Distribution and Infrastructure Review; United Nations: Washington, DC, USA, 2010.

22. Alliance, C. Citywide Pro-Poor Ger Area Upgrading Strategy of Ulaanbaatar City; United Nations: Washington, DC, USA, 2010.

23. Uddin, S.M.N.; Li, Z.; Ulbrich, T.; Mang, H.-P.; Adamowski, J.F.; Ryndin, R. Household greywater treatment in water-stressed regions in cold climates using an 'Ice-Block Unit': Perspective from the coldest capital in the world. J. Clean. Prod. 2016, 133, 1312-1317. [CrossRef]

24. Khattiyavong, C.; Lee, H.S. Performance Simulation and Assessment of an Appropriate Wastewater Treatment Technology in a Densely Populated Growing City in a Developing Country: A Case Study in Vientiane, Laos. Water 2019, 11, 1012. [CrossRef]

25. Seetaram, N.; Song, H.; Ye, S.; Page, S. Estimating willingness to pay air passenger duty. Ann. Tour. Res. 2018, 72, 85-97. [CrossRef]

26. Wilson, L.S.; Blonquist, T.M.; Hong, F.; Halpenny, B.; Wolpin, S.; Chang, P.; Filson, C.P.; Master, V.A.; Sanda, M.G.; Chien, G.W.; et al. Assigning value to preparation for prostate cancer decision making: A willingness to pay analysis. BMC Med. Inform. Decis. Mak. 2019, 19, 6. [CrossRef]

27. Hensher, D.; Shore, N.; Train, K. Households' Willingness to Pay for Water Service Attributes. Environ. Resour. Econ. 2005, 32, 509-531. [CrossRef]

28. Osman, K.K.; Claveria, J.B.; Faust, K.M.; Hernandez, S. Temporal Dynamics of Willingness to Pay for Alternatives That Increase the Reliability of Water and Wastewater Service. J. Constr. Eng. Manag. 2019, 145, 04019041. [CrossRef]

29. Menegaki, A.N.; Mellon, R.C.; Vrentzou, A.; Koumakis, G.; Tsagarakis, K.P. What's in a name: Framing treated wastewater as recycled water increases willingness to use and willingness to pay. J. Econ. Psychol. 2009, 30, 285-292. [CrossRef]

30. Vásquez, W.F.; Mozumder, P.; Hernández-Arce, J.; Berrens, R.P. Willingness to pay for safe drinking water: Evidence from Parral, Mexico. J. Environ. Manag. 2009, 90, 3391-3400. [CrossRef]

31. Faust, K.M.; Hernandez, S.; Anderson, J. Willingness to Pay for Perceived Increased Costs of Water and Wastewater Service in Shrinking US Cities: A Latent Class Approach. J. Water Resour. Plan. Manag. 2018, 144, 04018033. [CrossRef]

32. Tudela-Mamani, J.W. Willingness to pay for improvements in wastewater treatment: Application of the contingent valuation method in Puno, Peru. Rev. Chapingo Ser. Cienc. For. Ambient. 2017, 23, 341-352. [CrossRef]

33. Gawel, E.; Sigel, K.; Bretschneider, W. Affordability of water supply in Mongolia: Empirical lessons for measuring affordability. Water Policy 2012, 15, 19-42. [CrossRef]

34. Dupont, D.P. Water use restrictions or wastewater recycling? A Canadian willingness to pay study for reclaimed wastewater. Water Resour. Econ. 2013,1, 61-74. [CrossRef]

35. Genius, M.; Hatzaki, E.; Kouromichelaki, E.M.; Kouvakis, G.; Nikiforaki, S.; Tsagarakis, K.P.; Tsagarakis, K. Evaluating Consumers' Willingness to Pay for Improved Potable Water Quality and Quantity. Water Resour. Manag. 2008, 22, 1825-1834. [CrossRef]

36. Genius, M.; Manioudaki, M.; Mokas, E.; Pantagakis, E.; Tampakakis, D.; Tsagarakis, K. Estimation of willingness to pay for wastewater treatment. Water Supply 2005, 5, 105-113. [CrossRef]

37. Zhen, L.; Li, F.; Yan, H.M.; Liu, G.H.; Liu, J.Y.; Zhang, H.Y.; Du, B.Z.; Wu, R.Z.; Sun, C.Z.; Wang, C. Herders' willingness to accept versus the public sector's willingness to pay for grassland restoration in the Xilingol League of Inner Mongolia, China. Environ. Res. Lett. 2014, 9, 045003. [CrossRef]

38. Alves, B.; Rigall-I-Torrent, R.; Ballester, R.; Benavente, J.; Ferreira, Ó.; González, J.B. Coastal erosion perception and willingness to pay for beach management (Cadiz, Spain). J. Coast. Conserv. 2015, 19, 269-280. [CrossRef]

39. Withey, P.; Sullivan, D.; Lantz, V. Willingness to pay for protection from storm surge damages under climate change in Halifax Regional Municipality. J. Environ. Manag. 2019, 241, 44-52. [CrossRef] 
40. Taale, F.; Kyeremeh, C. Households' willingness to pay for reliable electricity services in Ghana. Renew. Sustain. Energy Rev. 2016, 62, 280-288. [CrossRef]

41. Yu, B.; Cai, Y.; Jin, L.; Du, B. Effects on Willingness to Pay for Marine Conservation: Evidence from Zhejiang Province, China. Sustainability 2018, 10, 2298. [CrossRef]

42. Hoffmann, S.; Qin, P.; Krupnick, A.; Badrakh, B.; Batbaatar, S.; Altangerel, E.; Sereeter, L. The willingness to pay for mortality risk reductions in Mongolia. Resour. Energy Econ. 2012, 34, 493-513. [CrossRef]

43. Gomez, J.; Papanikolaou, A.; Vassallo, J.M. Users' perceptions and willingness to pay in interurban toll roads: Identifying differences across regions from a nationwide survey in Spain. Transportation 2017, 44, 449-474. [CrossRef]

44. Le Tran, Y.; Siry, J.P.; Bowker, J.; Poudyal, N.C. Atlanta households' willingness to increase urban forests to mitigate climate change. Urban For. Urban Green. 2017, 22, 84-92. [CrossRef]

45. City's Governor's Office. Urban Development Trend 2030; City's Governor's Office: Ulaanbaatar, Mongolia, 2013.

46. Calia, P.; Strazzera, E. Bias and Efficiency of Single vs. Double Bound Models for Contingent Valuation Studies: A Monte Carlo Analysis; Centre for North South Economic Research, University of Cagliari: Sassari, Italy, 1998.

47. Hanemann, M.; Loomis, J.; Kanninen, B. Statistical Efficiency of Double-Bounded Dichotomous Choice Contingent Valuation. Am. J. Agric. Econ. 1991, 73, 1255-1263. [CrossRef]

48. León, R.; León, C.J. Single or double bounded contingent valuation? A Bayesian test. Scott. J. Political Econ. 2003, 50, 174-188. [CrossRef]

49. McMahon, P.; Moran, D.; Sutherland, P.; Simmonds, C. Contingent Valuation of First-Time Sewerage Provision in South-East England. Water Environ. J. 2000, 14, 277-283. [CrossRef]

50. Goodwin, B.K.; Offenbach, L.A.; Cable, T.T.; Cook, P.S. Discrete/Continuous Contingent Valuation of Private Hunting Access in Kansas. J. Environ. Manag. 1993, 39, 1-12. [CrossRef]

51. Tobin, J. Estimation of Relationships for Limited Dependent Variables. Econometrica 1958, 26, 24-36. [CrossRef]

52. McDonald, J.F.; Moffitt, R.A. The Uses of Tobit Analysis. Rev. Econ. Stat. 1980, 62, 318-321. [CrossRef]

53. Henningsen, G.H. Estimating Censored Regression Models in R using the censReg Package; Arne Henningsen University: Copenhagen, Denmark, 2012.

54. Lantz, V.; Trenholm, R.; Wilson, J.; Richards, W. Assessing market and non-market costs of freshwater flooding due to climate change in the community of Fredericton, Eastern Canada. Clim. Chang. 2012, 110, 347-372. [CrossRef]

55. List, J.A.; Gallet, C.A. What Experimental Protocol Influence Disparities between Actual and Hypothetical Stated Values? Environ. Resour. Econ. 2001, 20, 241-254. [CrossRef]

56. Loomis, J. What's to know about hypothetical bias in stated preference valuation studies? J. Econ. Surv. 2011, 25, 363-370. [CrossRef]

57. Loomis, J.B. 2013 WAEA Keynote Address: Strategies for Overcoming Hypothetical Bias in Stated Preference Surveys. J. Agric. Resour. Econ. 2014, 39, 34-46.

58. Harrison, G.W.; Rutström, E.E. Chapter 81 Experimental Evidence on the Existence of Hypothetical Bias in Value Elicitation Methods. In Handbook of Experimental Economics Results; Plott, C.R., Smith, V.L., Eds.; Elsevier: Amsterdam, the Netherlands, 2008; Volume 1, pp. 752-767.

(C) 2019 by the authors. Licensee MDPI, Basel, Switzerland. This article is an open access article distributed under the terms and conditions of the Creative Commons Attribution (CC BY) license (http://creativecommons.org/licenses/by/4.0/). 